"J. R. R." writes: In the past twenty years I have treated many patients with this condition by means of $x$ rays of medium penetration, administering about four-fittbs of the full dose through a $0.2 \mathrm{~mm}$. aluminium filter, at intervals of three weeks for several doses. The treatment cures many patients, and produces great improvement in most. I have never seen any ill effects from it.

\section{Income Tax.}

Private Use of Car.

"W. S. G." uses his car occasionally for private purposes, and consequently has been allowed only six-sevenths of the ruming costs. He has now replaced his car, and the inspector of taxes now objects to allowing him more than three-fourths of the cost of replacement. Is this correct?

* * $^{*}$ If a car is used partially for private purposes it is a fact that the whole of the cost cannot be allowed, but it is, of course a difficult matter to decide what is a reasonable percentage to exclude from the income tax statement. Mileage is probably the best basis, but it is seldom available for reference, as few (if any) practitioners find it worth while to keep the necessary reconds. Probably "W. S. G." will find it impossible to get away from the six-sevenths basis, but he seems to have good grounds for contending that the replacement cost should be dealt with on the same footing, aud six-sevenths, not three-quarters, allowed.

\section{Sale of Practice.}

"O. B. E." sold his practice as from Jane 30th, 1929. His successor purchased the "collector's book debts," but the other debts are being paid to "O. B. E." direct. How should his liability be calculated?

${ }^{*}{ }^{*}$ We assume that our correspondent has in the past accounted for his liability on the "cash basis," and that there are no special reasous which suggest that that basis was unfair to the Berenue. On that assumption it is clear that " $O$. B. E." is not liable to assessment ou the debts collected after be sold the practice, because they represent earuings of years for which he has accounted for his income tax liability. His liability to assessment, therefore, for the period April 5th to June 30th, when he sold the practice, is the tax dne on the amount of the earnings of the practice for that actual period; further, the Revenue is enticled to revise the assessment for the year to April, 1929, substituting for the amonit of the assessment the amount of the profits of the practice of that year.

\section{LETTERS, NOTES, FTO.}

\section{RadiotherapY in Skin Disteases.}

DR. C. H. C. DALTON (Ipswich) writes: I feel that I cannot allow the remarks of Dr. Harvey on the above subject (December $28 \mathrm{th}$ 1929, p. 1202) to pass without comment. A little time ago I was asked to treat a mau who was suffering from a severe attack o herpes zoster of seven weeks' duration. The distribution of the lesions was considerable, aud pain was more severe at this time than it had been previonsly. Second stage ery thema doses were given to the areas of the lesions with the mercury vapour lamp, and considerable relief was experienced, even after the first application. After six exposures; spread over a period of a fort night, the patient was almost completely relieved of his pain. lin my opiuion this form of treatment gives great relief in severe cases of herpes zoster.

Revocable Sterilization of the Female.

Dr. BINNIE DUNLOP (Loudon, S.W.), in the con'se of a letter on the above subject, writes: It woutd seem that in Grälenberg's ring (British Medical Journal, December 14th, 1929, p. 1134) we have at last a contraceptive so perfect as to provide a solution even for the problem of high-grade mentally deficient girls, unless it is objected that sterilization which is revocable is not to be advised in their case. I hope that many gynaecologists will now begin to test Gräfenberg's method, and that the ring and the inserting probe will soon be made in Englaud.

The Incidence of Cancer.

Mr. ERIC YULE, F.R.C.S. (Nuneatou), writes with reference to the preliminary note on an investigation into the incidence epidemiology, and ecotogy of cancer in Westmorland, which appeared in the Journal of December 7th, 1929 (4. 1062). He reoulls that a rather similar investigation was made by a committee appointed in Mrarch, 1898, by the Birmingham and Midland Counties Branch, a report being published in the Birminghain Medical Review, May to July, 1900. The chairBirmingham Medical Review, May to July, 1900. The chairman of the committee was Dr. R. M. Simon, and the homorary secretary Dr. E. N. Nason of Nuneaton. Mr. Yule hen reached are in accord with the opinions expressed by the Westmorland Field Commission. Cancer was found to occur more frequently in old than in new houses and districts, and some indication was fortheomiug of its possible transmissibility from one person to another; there was abuudant evidence of the existence of groups of houses in which cancer was found with marked freqnency, second and third cases appearing in the same house more of teu than could be explained by coincidence. A damp, ill-drained, waterlogged soil was said to be more frequently associated with a high cancer death rate than a dry, well-drained one, and prolonged contamination of the soil with production of the high cancer death rate.

Diplomas in OBSTETRICS.

DR. E. R. SMITHARD (London, N.15) writes: You have of late been giving us information about the new British College of Obstetriciaus and Gynaecologists, and in the Journal of December 21st, 1929 (p. 1173), you quote the president, Professor Blair Bell, as saying " soou the conucil hoped to discuss . . . the granting of a diploma in obstetrics and gynaecolony." surely the time has now come for a word of protest at this incessant multiplication now come for a word of protest at this incessant multiplication
of diplomas and qualifications in the realm of medicine. What is the object of the diploma? Is it merely to serve, like the D.P.H., D.P.M., D.L.O., etc., as a mark of proficieucy in a specialty, or is it the thin end of the wedse in bringing abont a triple qualification instead of the conjoint of the two older Colleges? If the former, it seems unnecessary, since we gather (from Professor Blair Bell's address) that the membership of the College will be open to the specialists in obstetrics and gynaecology as well as to the quasi-specialists in maternity work in the public health services; if the latter, surely it is agrin unnecessary, as being already provided for. What is the object of making a triple conjoint lettering instead of the present double one? We appear to be aping the eugineers in the incredible length of the abbreviations after our vames. And, further, if we are going to separate midwifery and gynaecology from general medicine and surgery, then why stop there? Why not a college of laryugologists, or a college of proctologists, each with its own qualifying examination and diploma; each with its grand council, fellows, members, and "general expeuses of not less than $£ 100,000$ "? Do let us try to preserve proportion. It is said that the College will be useful, inter alia, to stimulate research into such questions as materual naorbidity. But just because there every year," that in itself is surely no reason why the medical profession, through membership and diploma fees, should be fleeced to the extent of $£ 100,000$. Besides this, the College, as an entity, is superfinous. There are obvionsly very few advances to be made in obstetrics, while gynaocology is a nere and minor branch of surgery; and, any how, there is ample research work going ou at the present time for the 3,000 mothers without the aid of the new College.

\section{Automatic Machines for the Sale of Drugs.}

The president of the Pharnacentical Society of Great Britain (Mr. L. MIoreton Parry) has uttered au important warning in the name of his council on the dangers of automatic machines for the sale of drugs. He deplores the use of such contrivances, which has recently been on the increase, for the reason that when poisons or potent drugs are sold in this way none of the safeganrds contemplated by phaimacy legislation can be observed. The restrictions involved in such legislation were imposed to ensure the presence of someone able to give advice to a purchaser as to how a substance was to be used, to give warning when special care was necessary, aud also to refuse the supply of substances when they did not appear to be needed for a proper purpose, or when the purchaser was not a safe person to be trusted with them. With an automatic delivery machine there is nothing to prevent a child obtaining poisons such as potassium permangauate, or potent drugs such as aspirin, nor is there any guarantee against mistakes, such as taking packets from the wrong section. Mr. Parry begs members of his society to refuse to install automatic machines for this
purpose on their premises, and we feel sure that his timely warning will be endorsed by the medical profession.

\section{Corrigenda.}

THE National Radium Commission requests us to correct two statements which appeared in our article on "The Cancer Problem in 1929 " (Jauuary 4th, p. 26). In discussing the investigations conducted under the British Empire Cancer Campaigu we stated that " with the radium bought by the Natioual Radium Trustees it is proposed to construet several such [radium] bombs." The Council of the British Empire Cancer Campraign in its sixth anuual report, presented at a meeting held at the House of Lords on July 8th, 1929, made the following announcement: "With the increased supply of radium which will shortly be available as a result of the National Radium Fund, it is proposed that several snch bombs shall be available for the treatmeut of cases." The Radium Commission now informs us that it is not its present policy to purchase any other bombs than the one on loan at Westminster Hospital. It further asks ns to state that, while the qnestion of establishing a radop plant has been under consideration, nothing definite has yet been settled.

IR. George Mackay should have been described as Consulting Ophthalmic Surgeon to the Edinburgh Royal lufirmary (not "Consulting Surgeon ") in the herding to his article on "Control of Ocular Disease of Venereal Origin," published on Jaunary lith (p. 61).

VACANCIES.

NOTIFICATIONS of offices vacant in universities, medical colleges, and of vacant resident and other appointments at hospitas, will be found at pages $51,54,55,58,59,60,61$, and 62 of our advertisement columus, and advertisements as to partnerships, A

A short summary of vacant posts notified in the advertisement columns appears in the Supplement at page 23. 